\title{
Development Of Public Administration Program Development System in Rural Services in Order To Increase the Capacity Of Governance In Village East Java.
}

\author{
${ }^{1}$ Dr. Marnis, ${ }^{2}$ Dr. Samsir, ${ }^{3}$ Rofanita Rama, ${ }^{4}$ Dr. Priyono. \\ ${ }^{I}$ Management Science Department, Faculty of Economics, State University Riau Indonesia. \\ ${ }^{2}$ Management Science Department, Faculty of Economics, State University Riau Indonesia. \\ ${ }^{3}$ Management Science Department, Faculty of Economics, State University Riau Indonesia. \\ ${ }^{4}$ Management Science Department, Faculty of Economics, PGRI Adi Buana University, Surabaya ,East Java of \\ Indonesia
}

\begin{abstract}
This study aims to, knowing what aspects can be developed to increase the service capacity of village government, knowing the role of village and community in carrying out the functions and enhanced customer service and public administration, the factors that affect the improvement of rural public administration system to improve service capacity of village government, get a picture of the service capacity building and development of public administration system at the level of village government. The target to be achieved is to increase public administration system in the country so as to improve the capacity of government services to the rural community. From the study of theory, analysis and discussion on the findings of the field, it was found that the embodiment of the village administration, particularly on the object of research is still not optimal. Not optimal realization of the village administration, mainly reflected in: Still unclear performance standards that can be measured to determine the quality of the resulting output.
\end{abstract}

Key Words: Program Development, Development, Public Administration System, Service.

\section{Introduction}

In line with the theory of democracy understand "popular sovereignty", as stated Denhardt and Denhardt (2003) [1], the government from the people, by the people and for the people (government comes from the people, by the people and for the people). The three core values of democracy, can not be separated from each other. Power possessed by all government institutions, derived from the mandate of the people, should be run together with the people and shall be used for the benefit of the people. Cycle power comes from the people and the state should be accountable back to the people above, in short can be illustrated in the following chart. Figure 1: Cycle of People and State Power Must be accounted Back to the People.

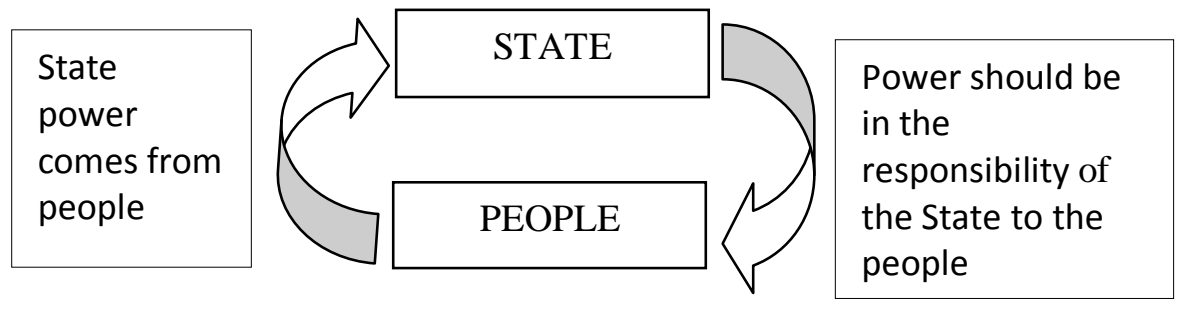

From the above, explicitly shows that the concept of a mandate or delegation of authority (delegation of power / authority), thus simultaneously embedded within it an element of "duty" (obligation / duty), especially the obligation to do so with a sense of responsibility (responsible ) and accountable (accountability) on the mandate of the power that has been accepted to the owner / grantor of power. In line with principle "government for the people" (government for the people), then the "performance" (performance) government in achieving the interests of the people, as well as will be the size / key criteria in assessing accountability in the administration of government power. As confirmed Keban (2004) [2], the realization and the real commitment of public accountability is only shown in the form of performance, including the performance of programs, institutions and government officials. Until the decade of the 90s, the realization of the interests of the people / public (public interest) through development activities and public services, many colored dominant role of government. Dominant role of the government is generally done by using the classical model of Weberian bureaucracy. This Weberian model, as confirmed Simmons and Dvorin (1977) [3], is characterized by an emphasis on: administrative power based on law, operate on a hierachical basis, culminate in a single head (monocratic), application rules are to be applied in an as impartial and objective manner, the individual 
bureaucrat is in a fixed position from roomates he can not escape, highly, discipline and keep its knowledge and its intentions secret (administrative authority based on law, work by principle of hierarchy, power centered on one leader, the rules are applied without impartially and objectively, every bureaucrat placed in the clear and cannot run away from its position, highly disciplined, and always protect and maintain the confidentiality of information as a source of knowledge). The model is patterned bureaucratic public administration, many considered to have an impact unfavorably, especially negative impact increasingly threatened survival (sustainability) development and public service. As confirmed Tjokrowinoto (2000) [4], that the goal of development and public services should be able to increase the capacity of communities growing on its own power (self-development capacity), it tends to make people more dependent on government services and assistance. The crisis of public services since the late 80 's, has encouraged the development of new thinking. concept of reinventing government by Osborne and Gaebler (1993) [5], and the concept of the new public management by Lane \& Rosen bloom (1992) [6]. The strengthening of democratic values issue is further encouraging the emergence of a new concept in the form of governance that many spearheaded by a number of international agencies such as UNDP and the World Bank, as well as experts such as Rodhes (1996) [7], with its governance theory and Stoker (1996) [8], with his regime theory.

In this concept of governance, contained three legs (three legs) and three domains (three domains). The three main legs governance include economic, political, and administrative, while the three major domains of governance, including the state (state), private sector (private), and society (community). The three domains, interact and carry out their respective functions. State institutions (government) serves to create an environment conducive political and legal, the private sector creates jobs and income, while public institutions a positive role in the interaction of social, economic and political, including the invited groups in society to participate in economic activities, social and political (LAN \& BPKP, 2000) [9]. In order to ensure the existence of a synergistic relationship between the state, private sector and civil society, requires the alignment (the degree of similarity) between positions (power / authority) and the role (obligation) between the components of the state, private sector and civil society so that they can act and react to each other (do control) to each other. If the degree of similarity is not proven, there will be a refraction towards good governance itself (Thoha, 2003) [10]. Accountability (accountability), is thus one of the principal / principal values of good governance. Schacter (2000) [11], in summary defines accountability as to explain and justify publicly the way its uses its power, and take prompt corrective action when Things go wrong (accountability as activities to provide an explanation for the actions and reasons justification in the use of power, and take corrective action when things go wrong). The village is the legal entity that has the authority to regulate and manage the interests of local communities based on the origin and local customs are recognized in the national system of government and was the District area (Wijaya, 2002: 65) [12]. Autonomy of the village and owned regional autonomy (decentralization) can be different, this difference as proposed by Taliziduhu Ndaha (1984: 6) [13], as follows:

Table 1: Differences village Autonomy

\begin{tabular}{|l|l|}
\hline \multicolumn{1}{|c|}{ Village autonomy } & \multicolumn{1}{c|}{ Village autonomy } \\
\hline 1. Native to Indonesia that existed since & 1. Derived from the western concept known \\
ancient times & in Indonesia until the early $20^{\text {th }}$ century. \\
2. Contents as if infinite, is flexible and elastic & 2. The contents between limited by statutory \\
3. In the traditional can sourced of indigenous & provisions and r unchanged. \\
law & 3. Gained from central government based \\
4. Aspects of the smaller set for a time sat & legislation \\
between by the government over the & 4. Aspects of the wider set \\
5. Rural region weights and levels of & 5. Urban and rural region weights and the \\
autonomy lighter & same level of autonomy \\
&
\end{tabular}

According to Smith in Juliantara (2000: 65) [14], states that: "In giving freedom to the Regional autonomy did not cause disintegration and will not reduce the degree of authority of the central government".

\section{Methods}

The research was conducted in the form of qualitative research, according to Bogdan and Taylor (1975) [15], a qualitative research method is a process of research that aims to collect and analyze the data descriptive form of writing, expression and human behavior that can be observed so as to obtain a thorough understanding (holistic) on a matter of this qualitative study was selected by a major consideration that accountability (accountability) is an issue very "sensitive". Besides requiring technical skills administration (management) specific, as well as crucial issues involving the interests of the authority and the ability of the actors involved to implement mutual obligations properly. Consideration is consistent with the assertion Islamy (2001) [16], who advocated the study of public administration should be assessed using postpositivisme paradigm. This is because 
the field of public service objectives should be more nuanced Three R's (Responsiveness, Representativeness, Responsibility) than the Three E's (Economy, Effectiveness, Efficiency). Data analysis was conducted by using the technique of "Interactive Analysis Model" conceived by Miles and Huberman (1992) [17], the analysis procedure is performed with 3 (three) phase is described by Miles and Huberman (1992) referred to as "Interactive Model ", as described below: Figure 2. Interactive Model Analysis.

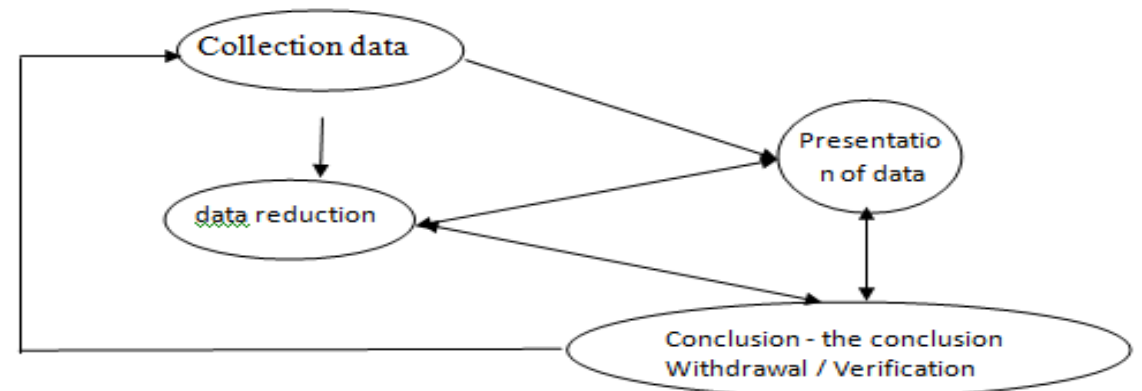

Source: Miles and Huberman (1992: 20).

Each standard requires a study to look at the degree of belief or truth of the research, so that the data collected can be accounted for. As confirmed Nasution (1998) and Moleong (2004) [18], inspection data can be done using the 4 (four) criteria: Degree of Confidence (Credibility). Diverted to an (transferability), Reliance (Dependability) and Certainty (Confirmability). Through analysis of the cross is done in a very diverse, within the validity of the data obtained. so the accuracy of the description and analysis, to illustrate the fact that actually happened in the implementation of the administrative system in the province of East Java village. The overall framework of the research methods described above can then be summarized in a chart as below. Figure 3 Framework of Accountability Research Methods Administration SKPD.

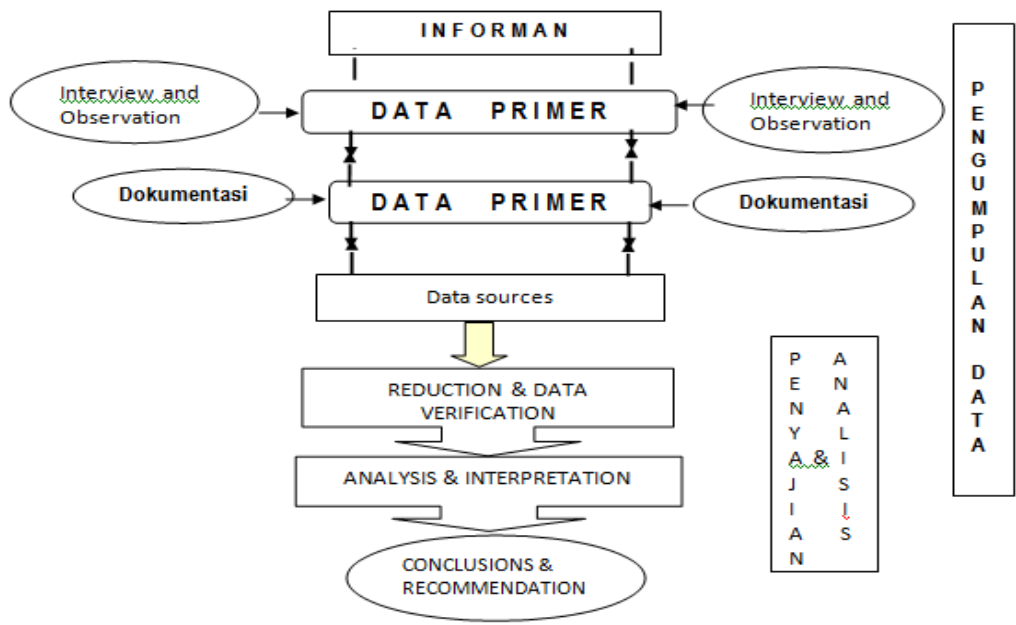

\section{Results}

Exposure field survey on the implementation of the Work Program Rural Development activities in the Village Administrative System in this study focused on the question of how the procedure of preparing and drafting the administrative system of the village. Based on interviews with informants, preparation procedures village administration system, is described as follows: The village already has an annual work program and activities. Village administration usually follows the habits ago-then (Interview, June 12, 2008). Similar explanations given by informants B as follows: first work plan prepared by the village head along with the rest of society. There is a pack of RT, religious leaders and the village. (Interview, June 19, 2008). Based on the results of interviews with informants $A$, the procedure of indicators and performance targets in the village, is described as follows: The process of determining these performance indicators and targets, made more on the basis of past experience. So they tend to contain many elements about and sometimes do not get confused. Determination of performance indicators and targets not thought to be preceded by doing activities aspirations of society (Interview, June 12, 2008). Based on the results of interviews with key informants in the substance and administration which has been described, it can be stated that although the procedure of preparing the work program has been implemented on the village in accordance with the stages of preparation of the administration, 
but qualitatively not been implemented optimally. Not optimal programming is mainly reflected in the indicators and performance targets based more past experiences and many are based on forecasts alone. Rather not based on the results of in-depth analysis of the development aspirations of the people and the burden of the demands or challenges / problems that actually happening in society. Influential Factors Against Government Rural Service Improvement To determine the extent of village officials in East Java to understand their main duty as a public servant, it can be seen from the respondents' answers, as the table below:

TABLE 2 UNDERSTANDING THE APPARATUS ON RURAL COMMUNITY JOB ANYWAY AS WAITRESS

\begin{tabular}{|l|l|l|}
\hline Respondents answer & frequency & percentage \\
\hline very understanding & 5 & $33,33 \%$ \\
understand & 10 & $66,67 \%$ \\
not understanding & - & $0 \%$ \\
\hline number & 15 & $100 \%$ \\
\hline
\end{tabular}

Sources: Data Processing Results.

Based on respondents' answers above it can be seen that all the apparatus village in East Java have to know what their main duty. However, they said that they knew only as a routine duties that have been implemented over the years. So it can be concluded that they do not work more as a routine, so there's no creativity from them to find effective ways to provide services to the community, so that what is given to what the public can meet the desires of the community.. Based on author interviews with respondents obtained information from government officials that even though they know what their main duty, but when they are dealing with the public does not always do the job according to what their main duty. This is due to the limited number of village officials, so that if one of the officers carrying out duties outside the office and at that moment there was a need of the apparatus is in $t$ office hat handles the required public affairs. The possibility of such a result suggests that the village officials seem less skilled in providing services, because they perform a task that is not their main duty. The respondent admitted in understanding fundamental duty in serving their communities get more direction and guidance from their immediate supervisor (village head), as shown in the table below:

TABLE 3 SOURCE APPARATUS UNDERSTANDING THE VILLAGE OF DUTY AS ANYWAY.

\begin{tabular}{|l|c|c|}
\hline \multicolumn{1}{|c|}{ Respondents answer } & frequency & percentage \\
\hline Through education and training / courses & 4 & $26,67 \%$ \\
Through experience in the task & 5 & $33,33 \%$ \\
Through mentoring and coaching supervisor & 6 & $40,00 \%$ \\
\hline \multicolumn{1}{|c|}{ number } & 15 & $100 \%$ \\
\hline
\end{tabular}

Sources: Data Processing Results

Information obtained from the respondents that the village head in giving guidance and direction to officers not limited to regular meetings, but on every occasion where officers have difficulty in the implementation of the ministry. This is done in anticipation of the public complaints against the behavior of government officials that less village did its job poorly..From the description above it can be concluded that the level of understanding of the basic tasks will influence the behavior of village officials in the public service. To determine the extent of understanding of government officials about their main duty as a public servant can affect their behavior in the service of society, can be seen in the respondents' answers in the table below:.

TABLE 4 EFFECT OF UNDERSTANDING OF DUTY AS A PUBLIC SERVANT OF BEHAVIOR TO SERVE.

\begin{tabular}{|l|c|c|}
\hline \multicolumn{1}{|c|}{ Respondents answer } & frequency & percentage \\
\hline A great effect & 9 & $60,00 \%$ \\
quite influential & 3 & $20,00 \%$ \\
no effect & 3 & $20,00 \%$ \\
\hline number & 15 & $100 \%$ \\
\hline
\end{tabular}

Sources: Data Processing Results

To determine whether the income level government officials in the village in East Java has met the expectations of the apparatus that is able to provide for his family including the cost of educating their children, can be seen in the table below:

TABLE 5 LEVEL INCOME / SALARY MEET Family Needs.

\begin{tabular}{|c|c|c|}
\hline Respondents answer & frequency & percentage \\
\hline $\begin{array}{l}\text { is sufficient } \\
\text { sufficient } \\
\text { insufficient }\end{array}$ & $\begin{array}{c}0 \\
3 \\
12\end{array}$ & $\begin{array}{c}0 \% \\
20,00 \% \\
80,00 \%\end{array}$ \\
\hline number & 15 & $100 \%$ \\
\hline
\end{tabular}

Sources: Data Processing Results

According to the authors of the respondents said that they received salaries can only provide for his family until 3 (three) weeks, it includes life-saver. Government efforts to raise salaries so far also not been felt 
by the village government officials, because every time the salary is raised prices also go up, sometimes the gains exceed the increase in their salaries. This situation is felt once at the time of the economic crisis that hit Indonesia today. According to them the new salary can be said ideal if increased three to four times salary now. From the information the author can salary apparatus village in East Java currently ranges between Rp. 450.000, - to Rp. 750.000, -. The village head respondents in this study confirmed this, but said what he personally received today is enough to make ends meet., Those who are married and their children coming of age to enter college costs a lot. For it is not surprising that the majority of the village officials have a side business as a way to provide for his family. To find out whether village officials in East Java has a side business can be seen from the respondents listed in the table below:.

TABLE 6 sideline apparatus in the village in east java.

\begin{tabular}{|l|c|c|}
\hline \multicolumn{1}{|c|}{ Respondents answer } & FREQUENCY & percentage \\
\hline Have a Side Business & 10 & $66,67 \%$ \\
Do not Have a Side Business & 5 & $33,33 \%$ \\
\hline \multicolumn{1}{|c|}{ number } & 15 & $100 \%$ \\
\hline
\end{tabular}

Sources: Data Processing Results

From the statements of the respondents can be concluded that the level of income has a significant influence in determining the behavior of a village officials in performing public service. Furthermore, to determine the suitability of the amount of salary received by government officials with the burden of assuming the task can be seen in the following table:.

Table 7 conformity with the salary received expense assignment / jobs.

\begin{tabular}{|c|c|c|}
\hline Respondents answer & FREQUENCY & percentage \\
\hline very appropriate & 0 & $0 \%$ \\
\hline Less Under & 3 & $20,00 \%$ \\
\hline not Available & 12 & $80,00 \%$ \\
\hline number & 15 & $100 \%$ \\
\hline
\end{tabular}

Sources: Data Processing Results

According to the authors, the answer is also the testimony of respondents indicated an expectation to the government to pay more attention to their well-being through improved payroll system. If their pay is high then they will no longer think about how to provide for the family, they will focus their attention on their main duty is to serve the community. If this can be achieved then the public service will increase both quality and quantity, and thus the public as customers who are entitled to the service will be satisfied. Experience while performing the task that is to source an understanding of the task / job of an employee so that in the end he has the ability to perform job duties. This happens in nearly all levels of the organization of government, especially at the level of lower-level governments outspoken as recognized by the respondents, through responses to questionnaires are summarized in Table 8 below:.

TABLE 8 Factors Shaping ability MASTERING TASK AND WORK

\begin{tabular}{|l|c|c|}
\hline \multicolumn{1}{|c|}{ Respondents answer } & frequency & percentage \\
\hline level of Education & 3 & $20,00 \%$ \\
Courses and Training & 3 & $20,00 \%$ \\
Experience in job & 9 & $60,00 \%$ \\
\hline number & 15 & $100 \%$ \\
\hline
\end{tabular}

Sources: Data Processing Results

According to information obtained from the author of the respondents, that the level of education they have less significant in shaping the ability of personnel in the performance of duties. This is because the level of education they have low average. According to the authors, that by looking at the life of the village officials who average more than 10 years, it is natural that the experience in a relatively routine task carried out will form the ability to carry out tasks / work. As the saying goes "style can be as usual", as well as for village officials in East Java, although they have low levels of education but they do the job every day then over time they can also perform the task / job. Furthermore, to determine the ability and willingness apparatus village in East Java in carrying out their duties and employment as well as in solving their own problems, can be seen in the distribution of respondents as shown in Table 9 below: 
TABLE 9 ABILITY ABILITY AND APPARATUS VILLAGE IN EAST JAVA.

\begin{tabular}{|l|c|c|c|c|}
\hline \multicolumn{1}{|c|}{$\begin{array}{c}\text { service } \\
\text { behavior }\end{array}$} & $\begin{array}{c}\text { very } \\
\text { Able }\end{array}$ & capable & $\begin{array}{c}\text { yet } \\
\text { Capable }\end{array}$ & number \\
\hline Handle Tasks and Jobs & $6(40 \%)$ & $9(60 \%)$ & $0(0 \%)$ & $15(100 \%)$ \\
\hline Problem Solving Self & $3(20 \%)$ & $9(60 \%)$ & $3(20 \%)$ & $15(100 \%)$ \\
\hline
\end{tabular}

Sources: Data Processing Results

Based on author interviews with respondents in this study obtained information that the task they are carrying out is relative as a routine, with experience of working an average of 20 years they are not too difficult to finish his work. They know how to handle a job there also know the character of the people who requested the service, it is because most of them come from villages as well. However, as now recognized to be more careful in providing services to the community. Communities that are more advanced and critical apparatus requires the village to be more transparent to the public first has to do with financial issues, such as government assistance intended for the public must be notified to the public, and not to be engineered for the benefit of village officials especially personal gain. While the respondents' answers can be traced that most respondents able to solve their own problems related to their tasks. And only a small fraction $(20.00 \%)$ who were not able to solve their own problems encountered in the implementation of their job duties. It is indicating that the ability of village officials have been good, so it will facilitate in providing services to the community. From author interviews with respondents in this study, information was obtained that they usually resolve the problems existing in its own new later if that they can not ask your boss in this sub-district to help solve it. to find out whether village officials in East Java to get praise from the head to the success of the work, a promotion based on the performance of the apparatus and the award of the public with the services performed by the apparatus can be seen in table 10 below:.

TABLE 10 AWARD OF THE WORK

\begin{tabular}{|l|c|c|c|c|}
\hline \multicolumn{1}{|c|}{ service } & always & Sometimes & NEVER & number \\
\hline Praise From the Chairman & & & & \\
\hline promotional Title & $0(0 \%)$ & $5(33 \%)$ & $10(67 \%)$ & $15(100 \%)$ \\
\hline The award of the & $0(0 \%)$ & $5(33 \%)$ & $10(67 \%)$ & $15(100 \%)$ \\
\hline
\end{tabular}

Sources: Data Processing Results

From interviews with respondents obtained information that the head of the village rarely gives praise to the officers, although they managed to complete the task well. According to the author it is because the head of the village do not yet know the impact of just praise the performance of the employees. Also it is not a culture of the leaders in the organization of government, especially at the lower levels like village. Based on interviews with respondents obtained information that their positions (Head of) because there is nothing else. This is justified by the head of the village who were respondents, almost 20 years there was no increase in village government officials, even if there was only a turn of the head of the village, in others not. Of 15 (Fifteen) employees in the office at this time all holding village office.. To determine the valuation of the courtesy and friendliness of the village officials may be reflected in the respondents' answers from the community in the tables below:

TABLE 11 Courtesy, friendliness AND VILLAGE Government Reform Speech Word.

\begin{tabular}{|c|c|c|c|c|}
\hline $\begin{array}{ll} & \text { service } \\
\text { behavior }\end{array}$ & very Polite & $\begin{array}{l}\text { quite } \\
\text { Polite }\end{array}$ & $\begin{array}{c}\text { NOT } \\
\text { POLITE }\end{array}$ & number \\
\hline Courtesy and friendliness & $11(23 \%)$ & $30(59 \%)$ & $9(18 \%)$ & $15(100 \%)$ \\
\hline Kata said & $6(12 \%)$ & $37(73 \%)$ & $8(16 \%)$ & 15 (100\%) \\
\hline
\end{tabular}

Sources: Data Processing Results

Based on interviews with respondents from the community obtained information that the public wants them to come every apparatus should also greeted with respect, invited in, asked what his need to come to the village, not left when they got to the village office. Although only a few states government officials Village is not polite, but it should be a concern employers to pay more attention village government officials to be more polite in serving the public so what can the public expect met. According to the authors disrespectful behavior shown by village officials because village officials tend not to know his position as a servant. He still felt as "pangreh" which served as a control. This culture is still attached to some of them the village officials in East Java. To change the culture takes time, but as a sub-district supervisor should always provide guidance and direction to subordinates consistently and patiently so that gradually but surely they can change for the better.Of response can be seen that most of the respondents (73\%) stated that officials in the village is quite polite-spoken, and $16 \%$ 
said no politely. This shows the arrogance still exists in the village officials. Based on interviews with respondents obtained information that sometimes casually talking with village officials and even sometimes lead to rough, considers himself a necessary, so that people have to accept it because it is needed. How Apparatus village in East Java dressed when providing care can be seen in the respondents' answers are listed in the following table:

TABLE APPARATUS 12 neatness VILLAGE AT PROVIDE SERVI.

\begin{tabular}{|l|c|c|}
\hline \multicolumn{1}{|c|}{ RESPONDENTS ANSWER } & frequency & Percentage \\
\hline faultlessly & 3 & $5,88 \%$ \\
pretty Neat & 25 & $49,02 \%$ \\
not Tidy & 23 & $45,10 \%$ \\
\hline number & 51 & $100 \%$ \\
\hline
\end{tabular}

Sources: Data Processing Results

Based on interviews with respondents obtained information that many village officials in East Java not maintain a uniform appearance when dealing with the public, but according to the respondents, one of the elements that create the impression of sympathetic in their dealings with government officials is a matter of neatness in dress. This is expressed in the proverb of Java "ajining sports clothing saka, saka lathi ajining self" which means body appreciated from how she dressed, and everyone appreciated the way he spoke. According to the authors lack officials influenced village of low educational background and age of those who are old, so they dress the way they are. In addition, they only wear uniforms obtained from agency rations provided by the workplace, which is not necessarily 3 (three) years providing clothing rations to government officials. While the uniforms worn every day, this causes wear clothes that look worn village officials, plus never worn shoes shined. Naturally, if the apparatus village in East Java seems less neat. To determine the extent to which Apparatus village in East Java can do justice in giving to the community can be seen in table 13 below

Table 13 Justice Services Apparatus Village In East Java Viewed From The Social Status

\begin{tabular}{|l|c|c|}
\hline \multicolumn{1}{|c|}{ Respondents answer } & frequency & Percentage \\
\hline very Fair & 6 & $11,76 \%$ \\
Fair enough & 27 & $52,94 \%$ \\
unfair & 18 & $35,29 \%$ \\
\hline number & 51 & $100 \%$ \\
\hline
\end{tabular}

Sources: Data Processing Results

From author interviews with some respondents obtained information that in some cases seen government officials in East Java village still looks discriminatory, such as prioritizing those with a higher social status as government officials and clerics and village officials prioritize families. This has led to the public at large are not satisfied with the services provided by village officials. These conditions led to complaints from the public complaints submitted either orally or by letter addressed to the apparatus through a suggestion box available in the office of the village in East Java. Unfair treatment from village officials also reflected in the respondents' answers are listed in Table 14 below:

Table 14 discriminatory service intensity Perceived by Community.

\begin{tabular}{|c|c|c|}
\hline Respondents answer & frequency & Percentage \\
\hline often & 11 & $21,57 \%$ \\
Sometimes & 24 & $47,06 \%$ \\
never & 16 & $31,37 \%$ \\
\hline number & 51 & $100 \%$ \\
\hline
\end{tabular}

\section{Sources: Data Processing Results}

Based on interviews with village officials obtained information that they are sometimes precede those who have government jobs, and also have a higher social status as scholars, businessmen and others because there is feeling of "ewuh pakewuh", not based on reason to receive benefits form of the material. According to the authors, such a situation is really alarming, because the government is supposed to provide to provide justice for his people, which is reflected by the behavior of apparatus in the field by providing services without distinguish communities from each other. Things like this should be stopped, because the image that is built up in the community will lead to negative impacts such as public distrust of the government, where such conditions have occurred in Indonesia today. For that as frontline government, village government officials should strive to restore the good image in the community so that they feel have a government that exists today, one of them, to do justice in providing services to the community. To determine whether the present village officials appropriate to the established rules, can be seen in the table below: 
Table 15 Precision Apparatus In Attendance Office Village.

\begin{tabular}{|l|c|c|}
\hline \multicolumn{1}{|c|}{ Respondents answer } & frequency & Percentage \\
\hline Always On Time & 17 & $33,33 \%$ \\
Sometimes the Right Time & 17 & $33,33 \%$ \\
Not the Right Time & 17 & $33,34 \%$ \\
\hline number & 51 & $100 \%$ \\
\hline
\end{tabular}

Sources: Data Processing Results

According to some respondents, when they are early in the morning (time office hours) requires services that are somewhat in a hurry they had to wait for a village officials were not present, it is disappointing the people who happen to need the service as soon as possible, because they have to finish another job who also urged his time. It would not have happened if the officers arrive on time in accordance with the rules. According to the author for whatever reason, obviously it is a form of discipline on the part of the government apparatus, which should not be done. Moreover, the village government officer behavior and actions are always on the highlight because of his position as a public servant and dealing directly with the public. To determine the extent of readiness of the village officials during working hours, can be seen in the table below:

TABLE APPARATUS 16 EXISTENCE AND READINESS TO WORK HOURS VILLAGE.

\begin{tabular}{|l|c|c|}
\hline Respondents answer & frequency & Percentage \\
\hline Always There and Ready at the Office & 22 & $43,14 \%$ \\
Sometimes Not in the Office and Not Ready & 24 & $47,06 \%$ \\
Never There and Ready at the Office & 5 & $9,80 \%$ \\
\hline number & 51 & $100 \%$ \\
\hline
\end{tabular}

Sources: Data Processing Results

Based on interviews with respondents, some of whom were forced to wait up to several hours to get service from the village officials because the officials who deal with issues that are not being taken care of in the office, with no clarity of his whereabouts. Things like that would make disappointed, because the business is supposed to be finished late finally resolved. To find out whether village officials in East Java provide completely can be seen in the following table:.

TABLE SERVICE BY GRANTING 17 completenesS VILLAGE GOVERNMENT APPARATUS.

\begin{tabular}{|l|c|c|}
\hline \multicolumn{1}{|c|}{ RESPONDENTS ANSWER } & frequency & Percentage \\
\hline Always Given To complete & 34 & $66,67 \%$ \\
Sometimes Provided Not Up Completed & 15 & $29,41 \%$ \\
Never Completed & 2 & $3,92 \%$ \\
\hline number & 51 & $100 \%$ \\
\hline
\end{tabular}

\section{Sources: Data Processing Results}

Based on interviews with the respondents obtained information that some of those who sometimes receive services not to completion, this is because there is something very important matters that should be resolved by the village government officials at that time. However, respondents from the community can her excuse, and village government officials usually delegate it to another apparatus to complete. If it's none of his business can not be delegated to other officials, then the next day or at another time a pending matter will be continued to be resolved. From the information obtained, no officers were deliberately delaying the completion of a business, that matters can be resolved that day to be completed that day trying anyway. then responsibilities village officials also can be observed from the rigor and precision of employees in providing services. To determine the level of accuracy and precision apparatus village in East Java can be seen in the following table:

Table 18 Fidelity And Accuracy Apparatus Level Village Provide Services In East Java.

\begin{tabular}{|l|c|c|}
\hline \multicolumn{1}{|c|}{ Respondents answer } & frequency & Percentage \\
\hline Very Thorough and Careful & 8 & $15,69 \%$ \\
Quite Thorough and Self-Quiz & 39 & $76,47 \%$ \\
Not Thorough and Not Careful & 4 & $7,84 \%$ \\
\hline number & 51 & $100 \%$ \\
\hline
\end{tabular}

Sources: Data Processing Results

According to the authors, based on observations in the field, village government officials in East Java is quite thorough and careful enough, it proved very rare missing files, damaged files and repeatability requirements in one type of service. This is probably caused also by the experience of officers who have had a job for years. Of all the descriptions of the behavior of government officials in the village in East Java in delivering services to the people above, it can be concluded that there are many behavioral apparatus in providing services that do not indicate what should be done by government officials as a public servant, so as 
not to give satisfaction to the society is characterized by the presence of complaints and complaints from the public to the government officials in the Village of East Java.

\section{Discussion Of Findings.}

The preparation of the work program is one of the key components in the implementation of performance-based management, the main media are well placed to improve the accountability of the performance of each government institution (Mohammed, 2007) [19], or in other words, resource management, management development, more based on the value of new values are more performance-oriented, value for money, transparency, participation, fairness, efficiency, control and accountability. Embodiment of new values is a necessary prerequisite for the creation of financial management really oriented towards the interests of the people and accountable to the people (Mardiasmo, 2002) [20]. From various studies do experts, policy decentralization or delegation of authority from the center to the regions have the potential to enhance the effectiveness of governance and development in the region. As emphasized by Smith (1985) [14], and Cheema and Rondenelli (1988) [21], however, the policy of decentralization or delegation of authority also has the potential for ineffectiveness in governance and development in the region, due to various factors who will be involved affect implementation. Smith (1985) identifies two principal obstacles to the decentralization efforts, the scale of operations at the local government level between the very small to the effectiveness of government interventions to address social and economic inequality, as well as community participation emerged, countries tend to return to the form of planning and management orthodox even repressive. Mawhood (1987) [22], confirmed 3 (three) the trend of decentralization policy barriers local executives are more dominant than the legislature, local governments generally lack the financial capacity, and the lack of ability of local authorities in the implementation of the policy fact indicates that the implementation of such a finding decentralization authority in the Act 32 of 2004 on Regional Government and Law No. 33 year 2004 on the financial balance regional and other legislation related to other Local Government, was only able to provide conceptually normative expectations, but not at the level of implementation. The concept is so good, the application has not been properly implemented optimally. This is caused by several things, among others: the low capacity of local officials, the slow adjustment of the central institutional (resistance), unresolved division of authority between the central government and the regions and between regions, it is still not optimal compatibility and integration aspects of regulatory / policy between the central and local and policy center (sector) that is not in line with the decentralization policy, and yet optimally understood and local governance that is based on the Administrative System of the Republic of Indonesia (SANKRI) as a guiding principle .. Influential Factors Against Government Rural Service Improvement.

System administration is a principle that ensures that any activity can be accounted for governing publicly by actors to the parties affected by the implementation of the policy. Decision making in public organizations involve many parties. Therefore it is natural that policy formulation is the result of an agreement between the citizen electorate (constituency) political leaders, technocrats, bureaucrats or administrators, and implementers in the field.

\section{Conclusion.}

From the study of theory, analysis and discussion on the findings of the field as it has been described before, finally some important conclusions can be drawn as follows:.

1. Embodiment of the village administration, particularly in the research object is still not optimal; 2. Not optimal realization of the village administration, mainly reflected in:.

a. Still unclear performance standards that can be measured to determine the quality of the resulting output. b. Supervision as part of the learning process as well as providing vehicle interaction system executable sanctions, awards not or not running as expected.. c. Weak tendency competencies related to the use of information technology to e-government is one of the challenges and needs. d. Relationships and a lack of communication open between the apparatus. e. Education and training programs within the government, not competitive to the needs of the expected competencies of training: in addition to the determination of the method of training without..

3. Preparation of village administration system as a complex activity, without supported by the creation of conditions conducive environment such as human resources professionals, actors and support the commitment of adequate resources, led to the administration of the village used to meet obligations merely formal and not been able to become the media for major performance improvements..

4. Implementation of accountability of the village administration, without the support of the programming procedures are clear and systematic work, has made accountability process and product itself can not be done in a professional manner and produce optimal results. 


\section{References}

[1]. Denhardt, Robert B., and Denhardt, Janet Vinzant, (2003) The New Public Service: Serving Rather than Steering, Journal of Public Administration Review, Vol. 60, No. 6, p: 549-559.

[2]. Keban, Yeremias T, (2004), Enam Dimensi Strategis Administrasi Publik Konsep, Teori dan Isu, Gava Media, Yogyakarta

[3]. Simmons, Robert H. and Dvorin, Eugene P., (1977) Public Administration: Value, Policy and Change, Alfred Publishing Co. Inc.: Washington, D.C.

[4]. Tjokroamidjojo, B. (2002) Good Governance: Paradigma Baru Manajemen Pembangunan. Jurnal Administrasi Negara Vol. II, No. 1.

[5]. Osborne, D. \& Gaebler, T. (1993) Reinventing Government: How the Entrepreneurial Spritit is Transforming the Public Sector. Reading MA, Addison-Wesley.

[6]. LAN-BPKP, (2000) Akuntabilitas dan Good Governance, Jakarta: (Modul AKIP).

[7]. Rhodes, R.A.W. (1996) The New Governance: Governing without Government, Political Studies. XLIV, $652-667$.

[8]. Stoker, G. (1998) Governance as Theory: Five Propositions, UNESCO.

[9]. LAN-BPKP, (2000) Akuntabilitas dan Good Governance, Jakarta: (Modul AKIP).

[10]. Thoha, Miftah, (2003) Birokrasi dan Politik di Indonesia. Rajawali Press, Jakarta.

[11]. Schacter, M. (2000) When Accountability Fails : A Framework for Diagnosis and Action. Institute on Governance, Canada.

[12]. Widjaja, H.A.W., (1993). Pemerintahan Desa dan Administrasi Desa Menurut UU No. 5 /1979, Jakarta: Raja Grafindo Persada.

[13]. Widjaja, H.A.W., (2001)Pemerintahan Desa/Marga Berdasarkan UU No. 22/1996 Tentang Pemerintahan Daerah, Jakarta: Raja Grafindo Persada.

[14]. Ndraha, Taliziduhu., (1991). Dimensi-dimensi Pemerintahan Desa. Jakarta: Bumi Akasara

[15]. Ndraha, Talilzuduhu., (1984). Pembangunan Desa dan Administrasi Pemerintahan Desa. Jakarta: Yayasan Karma Dharma - IIP Depdagri, Jakarta.

[16]. Smith, B.C. (1985) Decentralization: The Territorial Dimension of the State, Goerge Allen \& Urwin: Sydney, Australia.

[17]. Taylor, S.J. \& Bogdan, R. (1984) Introduction to Qualitative Researh Methods: The Search of Meanings. John Wiley \& Sons, New York

[18]. Islamy, M. Irfan, (1998) Agenda Kebijakan Reformasi Administrasi Negara, Pidato Pengukuhan Jabatan Guru Besar dalam Ilmu Kebijakan Publik pada Fakultas Ilmu Administrasi, Universitas Brawijaya, Malang.

[19]. Moleong, Lexy J., (2004) Metode Penelitian Kualitatif. Remaja Rosdakarya, Bandung

[20]. Muhamad, Ismail, (2003), Pelayanan Publik Dalam Era Desentralisasi, Disampaikan dalam acara Seminar "Pelayanan Publik

Dalam Era Desentralisasi" yang diselenggarakan oleh Bappenas, pada tanggal 18 Desember 2003, di Jakarta

[21]. Mardiasmo, (2002) Otonomi \& Manajemen Keuangan Daerah. ANDI, Yogyakarta.

[22]. Cheema, G.S. and Rondinelli, D.A., (1987) Decentralization and Development: Policy Implementation in Developing Countries, Sage Publications Inc, California.

[23]. Mawhood, P. (1987) Local Government in The Third World. John Wiley \& Sons, New York. 